\title{
WATER QUALITY CHANGES AND ITS TRENDS IN THE CZECH REPUBLIC
}

K. Alamets, M. Bicanová, P. Judová, H. Pärnamets, L. Ronczyk, S. Rödlová: Water Quality Changes and Its Trends in the Czech Republic. - Geografie - Sborník ČGS, 109, 2, pp. 181-188 (2004). - The state of environment in 1989 was a result of political and economic development of Czechoslovakia during preceding 40 years. Political and economical changes were the reason why the water quality in the Czech Republic has been significantly changing since 90's. In this text we want to describe not only these changes, but also their causes, includingthe legislation changes due to preparation for the membership in the EU and their consequences in the field of water management, water quality, water ecosystems restoration and others.

KEY WORDS: water quality - water pollution - restoration - water law - EU enlargement (admittance to the EU) - IP Erasmus.

\section{Introduction}

This work attempts to introduce the contemporary state and development of the surface water quality in the Czech Republic. First, the information about the water quality before 1989 is briefly outlined. The essential part of the study presents a historical overview of the water quality changes.

Surface water quality is defined by several very complex parameters; therefore it is difficult to say something about the water quality trends, as the indicators of water quality can change independently on each other. It means that some features can improve, but others can deteriorate at the same time, and in this situation any evaluation is a difficult task.

\section{Study Area, Methods, and Problems}

Under the Intensive Programme (29716-IC-1-2001-1-ERASMUS IP-5) Water management in transition countries, on the subject "Water resources - their management and protection of water resources in central Europe", working group "Water Quality" studied the problems linked with given themes in following phases:

1. Preparation phase: All members of the working group received an essay with basic information about water quality and connected problems before the beginning of the Intensive Programme.

2. On-site-learning phase:

a) Expert lectures at the Charles University, Prague

b) Excursions with lectures in specialized organizations, facilities and 


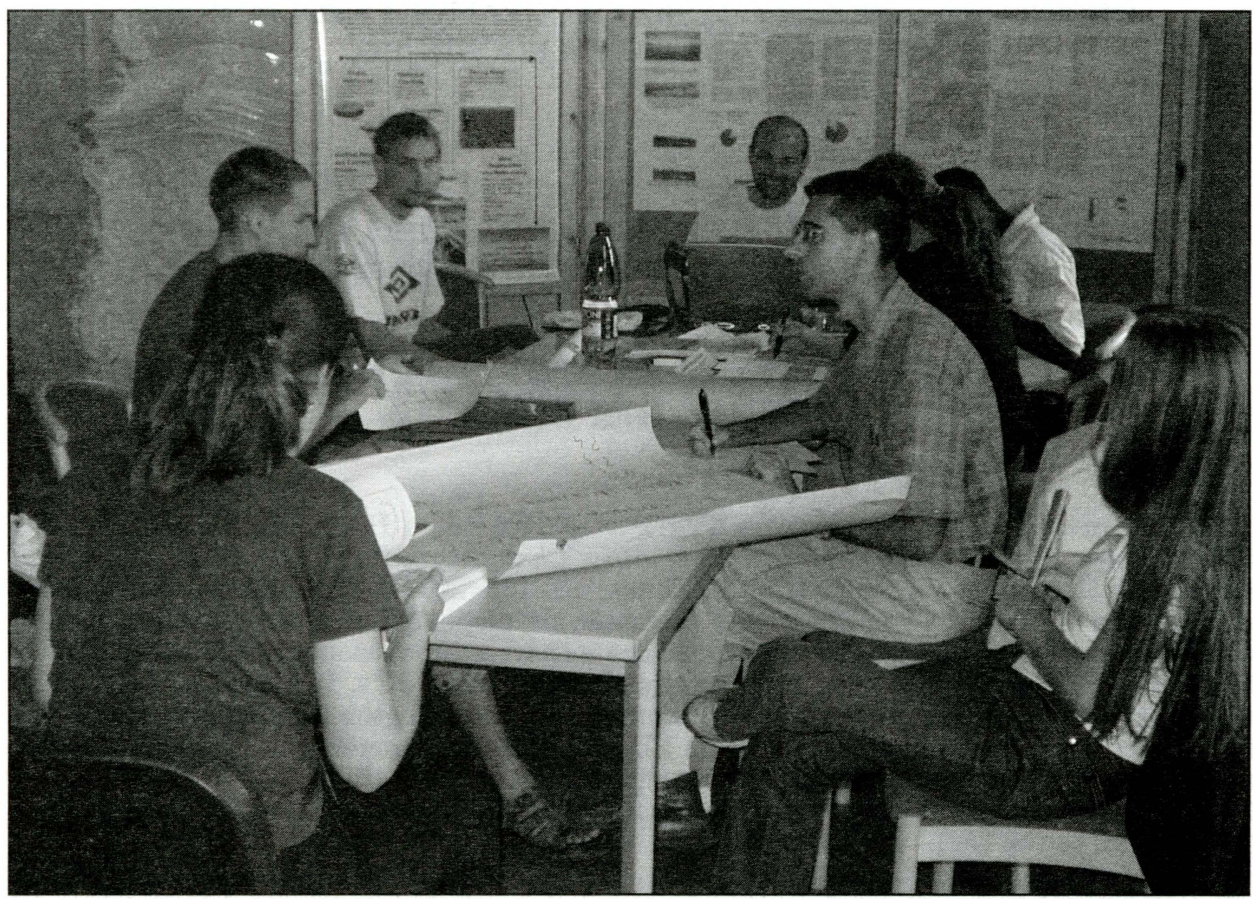

Fig. 1 - Water quality working group discussing its presentation

areas: Povodí Vltavy a.s. (Vltava catchment organization), Prague Municipal sewage treatment plant, Velké Popovice Brewery water treatment plant, small treatment plant in Pyšely village, polluted Pyšely stream, half restored pond in Velké Popovice and restored part of Stropnice river catchment

c) Measuring of basic water quality parameters in Pyšely stream

3. Post-processing phase: Discussion, processing and presentation of results (Fig. 1).

\section{Water Quality in Czechoslovakia before 1989}

The unsatisfactory ecological state of water ecosystems in 1989 corresponded to the whole state of environment and was a result of political and economic development of Czechoslovakia.

Considering that majority of rivers spring within the territory of the Czech Republic and only few flow in from abroad, the water pollution is practically only domestic product, which is in addition flowing into neighbouring countries.

The water quality is being monitored since 1950's in some profiles and since 1963 regularly in fixed network of checking profiles. There are 284 profiles, which are observed once in every month (www.chmi.cz). The monitoring is based on physical and chemical parameters, heavy metals, specific organic compounds and biological and microbiological samples. Water quality is described by a scale of 5 classes. 
The main sources of water pollution are towns and communities, industrial factories and agriculture (Pitter 1999). Detecting of sources helped to establish many precautions, including production restrictions and limits of pollution, but it was mostly ineffective because of insufficient realization and many "exceptional" allowances. The main problems were (www.env.cz):

- Organic biodegradable pollution

- Surface erosion and diffuse runoff of fertilizers

- Frequent oil accidents (500 annually) accidental water pollution

- Contamination with specific compounds that were not included in limits and were not regularly monitored.

Another problem was in insufficient technical equipment of wastewater treatment plants, so the water was not treated enough. Treatment plants in many cities of regional importance (over 100000 inhabitants) were overloaded and in some of them there were even no treatment plants.

\section{Water Quality Changes after 1989}

In development of the water quality the most significant change occurs at the beginning of the 90s. The political system change in the $1989 \mathrm{had}$ an impact on water quality throughout the period of economic crisis. The environmentalists call it "gift-effect", because the economic crisis resulted in a significant reduction on pollution. After the change of regime the mining, the chemical and textile industry as well as the farming decreased their production, and at the same time the gradually rising prices of drinking and irrigation water led to a decrease in the water consumption.

So the economical transformation brought the significant change in the pollution sources structure and the components of water quality. A characteristic feature of the pollution sources change is the fast decline of impact of the point sources of pollution as a result of decreasing industrial production, restructuring and international pressure (Langhammer 1999). EU and Germany financially supported construction and modernisation of sewage treatment plants in the beginning of the $90 \mathrm{~s}$.

The main significant improvement was reduction of heavy metals, radioactive pollutants, $\mathrm{BOD}_{5}, \mathrm{COD}$ and $\mathrm{N}-\mathrm{NH}_{4}$. In spite of decreasing agricultural activities and lower usage of the $\mathrm{N}-\mathrm{NO}_{3}$ fertilizers, the contamination has not shown any significant changes (Janský 2002). Phosphorus load is still high because of missing third step of treatment in many treatment plants, which causes wide spread eutrophication problem (Fig. 2).

Discharged pollution decreased remarkably compared to the 1990 level. The recent situation in communal facilities in the Czech Republic is (www.env.cz):

- $89,8 \%$ of population is connected to public water supply systems

- 77,4 \% of population living in houses is connected to public sewerage systems

- all municipalities with population equal or above 10000 have waste water treatment plant. 


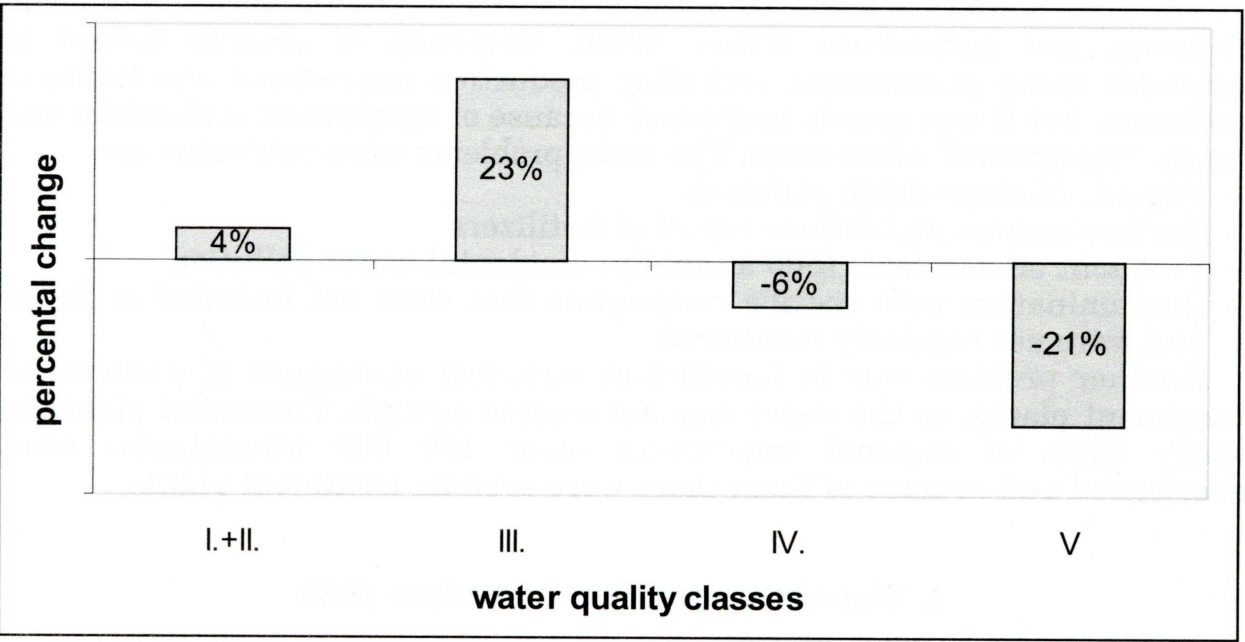

Fig. 2 - Relative change of water quality classes in the Czech Republic in the years 1991-1992 and 1999-2000. Source: Ministry of Environment, www.env.cz.

\section{Water Quality in Small Watersheds}

Water quality monitoring of small watersheds and small water reservoirs is being run under the auspices of agriculture water authorities. There are six monitoring programs in the Czech Republic. Four of them are specialized on the streams and two on water reservoirs.

Indicators of the volume of nutrients $\left(\mathrm{N}-\mathrm{NH}_{4}, \mathrm{~N}-\mathrm{NO}_{3}\right.$ and PT), toxic PCBs and $\mathrm{PAH}$ decreased. Also heavy metals $(\mathrm{Cu}, \mathrm{Cr}, \mathrm{Zn}, \mathrm{Pb})$ and faecal contamination (enterococcus) have debased during 2002. Very complex task for the future is to solve 'non-point' pollutants entering watercourses from wide area of the catchment. The contamination is generated by agricultural and small municipal sources. The greatest task of coming years will be the construction of missing wastewater networks and treatment plants. Without such an investment the EU Water Directive is unachievable. This environmental situation has historical roots, due to the fact that environmental aspects were neglected during the socialism and now it requires billions Euro and a new practice in agriculture.

\section{Changes in Management and Protection of Water Sources}

The geographical position of the Czech Republic brings the responsibility for quality of water flowing to the neighbouring countries. International treaties can constitute necessary pressure in the matter and especially Germany - as a downstream country of Elbe River and also EU member - tries to force the Czech water authorities to protect and improve surface water quality.

Main changes that the European Union brings into water sector, relates to EU Water Framework Directive 2000/60/EC. According to this Directive, the Czech water law 254/2001 was created in the year 2001. In the Czech Republic it is the Ministry of the Environment and the Ministry of Agriculture that are responsible for implementation. 
The Czech water law includes a significant range of rules and recommendations and their implementation requires participation of technical institutions and other experts. In the Czech Republic, several supporting organisations are involved (T.G.M. Water Research Institute, the Czech Hydrometeorological Institute, 5 River Basin Companies, etc.).

The most important fields that are influenced by the transposition of new legislation are urban wastewater treatments, nitrates pollution from agriculture, dangerous substances, bathing water quality, drinking water, groundwater protection and quality of fresh water as an environment for the water life.

In the Czech Republic there were designated areas according to the EU directives - in terms of the Urban waste water treatment directive (91/271/EEC), the whole Czech Republic is a sensitive area, the Nitrate directive (91/67/EEC) identifies vulnerable zones on $36 \%$ of the Czech Republic.

There is a need to ensure construction and reconstruction of sewerage networks and wastewater treatment plants particularly in settlements between 2000 and 10000 inhabitants and reconstruction and intensification of waste water treatment plants in towns and cities of over 10000 inhabitants. The Czech Republic requests for these steps the transitional period ongoing until December 31st, 2010.

\section{Restoration of Water Ecosystems}

The water quality is relatively closely connected with ecological state of landscape. To ensure international obligations, the International Commissions for Protection of Elbe, Danube and Odra Rivers were established. It was not the first step to improve water ecosystems. The Czech government proclaimed the Program for restoration of water systems in 1992 (Novotná, Kender 1997).

The goals of this program are (Láger, www.priroda.cz):

- To undo negative results of previous unsuitable land arrangements and unsuitable land management and to adapt drainages of large areas.

- To support and increase water retention capacity of landscape by slowing down surface and subsurface runoff.

- To increase infiltration and retentive abilities of soil profile and retaining of water in reservoirs, lakes or wetlands.

- To restore natural function of water streams by correcting their unsuitable modifications.

- To create protective bank areas and new bank vegetation.

- To make relatively stabile river basin.

- To support natural cleansing capacity of water by various arrangements of stream components.

- To increase stability of water regime by decreasing differences between minimal and maximal flow, etc.

This program is financed from the state budget from governmental grant. A working group from Ministry of Environment and some other organizations supervise the programme and are responsible for it (Fig. 3, 4).

\section{Future Trends of Water Quality}

The co-operation is the key because water provides the basis for a whole range of activities from agriculture and fishing to power generation, industry, 


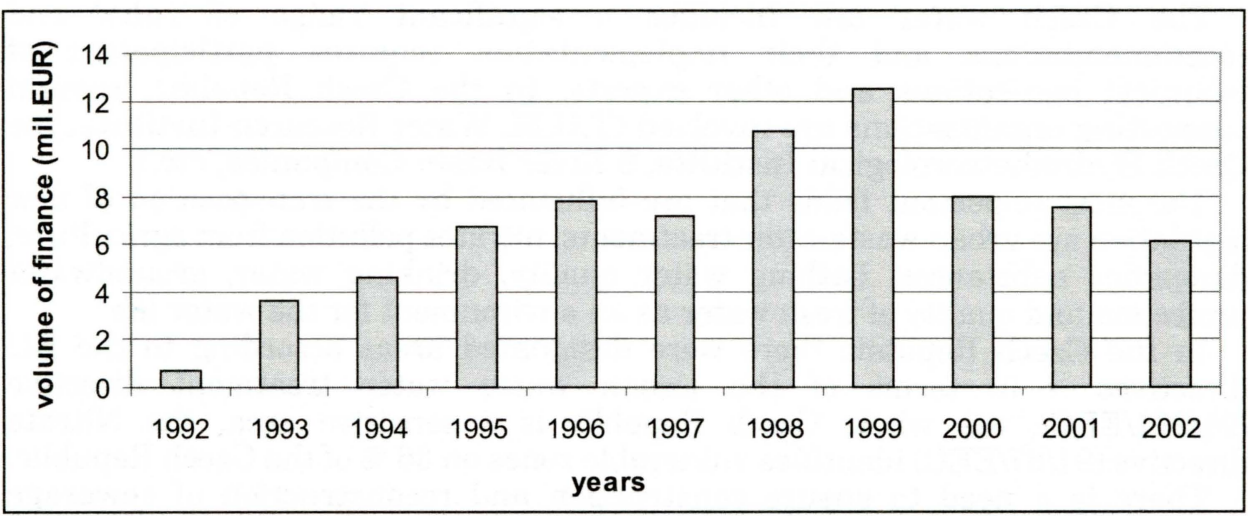

Fig. 3 - Amount of money given to restoration programmes in the Czech Republic. Source: Ministry of Environment, www.env.cz. During the years 1992-2002 nearly 2000 projects were realized. About 2,4 milliard CZK (75,5 millions) were invested. In the first period (1992-1995) relatively small projects $(0,5-1,5$ millions CZK) were financed. In the second period (1995-2002) bigger projects (1-3 millions CZK) overtook (www.env.cz).

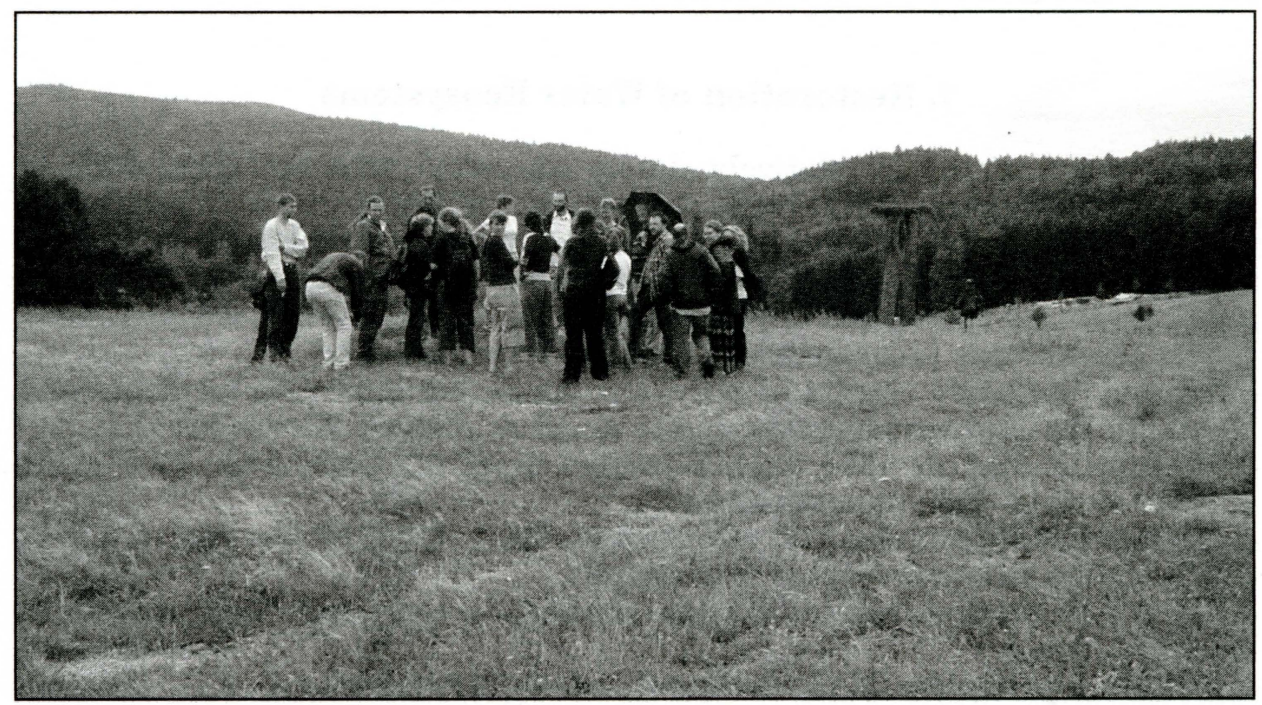

Fig. 4 - Visiting of restored part of Stropnice River

transport and tourism. Also citizens, NGOs and authorities at all levels of government should be more involved, which will help to ensure that the demanding timetable of the EU legislation requirements will be met. The Framework Directive aims to prevent pollution at source and sets out control mechanisms to guarantee that all pollution sources are managed in a sustainable way.

Although today much of Europe's ground waters and surface waters are polluted, they should all reach "good status" by the year 2015 .

Hopefully the same situation will be reached in the Czech Republic. It is important that the new approaches of EU have to be transposed according to the local conditions in the country considering the existing institutional framework, traditions, possibilities, needs and availability of resources. 
Taking into account the real and substantial needs of the country, the changes brought by EU are not overambitious and impossible anymore.

\section{Conclusion}

Our working group was aimed at water quality changes and their prediction in the future. Members of our group estimated from accessible materials, lectures and excursions, that surface water quality in the Czech Republic have been improving since the beginning of $90 \mathrm{~s}$. The main reason is agriculture management changes and construction and reconstruction of sewage treatment plants, which still continues.

Thanks to another frame of reference on nature, higher pressure on improving of whole ecosystems emerged. Because of it water ecosystems restoration programmes were established and they try and deal with this problem.

\section{References:}

JANSKÝ, B. (2002): Changing water quality in the Czech part of the Elbe catchment area in the 1990s. Geografie - Sborník CGS, 107, No. 2, ČGS, Praha, pp 98-110.

JANSKÝ, B. (2002): Viv zemědělství na jakost vod v českém povodí Labe, 10. Magdeburský seminář o ochraně vod, Povodí Labe, VUV TGM, Praha, pp. 305-306.

LÁGER, A. (2003): Revitalizace říčních systémů, www.priroda.cz.

LANGHAMMER, J. (1999): Vývoj kvality vody v Labi - aplikace matematických modelů jakosti vody. PhD. Thesis, PřF UK, Praha, $235 \mathrm{p}$.

LANGHAMMER J. (2003): Water Quality changes in the Elbe River Basin, rkp.

NOVOTNÁ, D., KENDER, J. (1997): Program revitalizace ř́čních systémů - 6 let existence. In.: Krajinotvorné programy - sborník konference s mezinárodní účastí, Příbram, pp. 910.

PITTER, P. (1999), Hydrochemie. 3. vydání, Nakladatelství ČVUT, Praha.

Revitalizace vodního prostředí, AOPK ČR, Praha 2003, 144 p.

The Czech Environmental Institute (2001): Statistical environmental Yearbook of the Czech Republic. Czech statistical office, Ministry of Environment of the Czech Republic, Praha, $551 \mathrm{p}$.

Www pages:

Czech Hydrometeorological Institut pages, www.chmi.cz

Ministry of Environment pages, www.env.cz

EU Water Framework Directive 2000/60/EC

Urban Waste Water Treatment Directive (91/271/EEC)

Nitrate Directive (91/67/EEC)

Shrnutí

\section{TRENDY VE ZMĚNĚ KVALITY VODY V ČESKÉ REPUBLICE}

V rámci mezinárodního semináře „Intenzivní program - (29716-IC-1-2001-1-ERASMUS IP-5) Management vodního hospodářství přistupujících zemí“ na téma „Vodní zdroje -management a ochrana vodních zdrojů ve střední Evropě" se mezinárodní pracovní skupina „Kvalita vody“, složená ze studentů a pedagogů několika evropských universit, soustředila na problémy spojené se změnou a vývojem kvality povrchových vod v České republice. Během semináře vyslechla tato skupina několik odborných přednášek, navštívila specializované instituce a pracovala v terénu. Cílem práce bylo mimo jiné i seznámit členy skupiny s vývojem kvality vody v České republice a jeho příčinami. 
$\mathrm{V}$ minulém období byla díky nešetrnému vztahu $\mathrm{k}$ přírodě zdevastována značná část životního prostředí včetně jeho vodní složky. Na znečištění se nejvíce podílely organické látky z bodových zdrojů znečištění a splach průmyslových hnojiv ze zemědělských ploch. K dalšímu znečištování - především ropnými látkami - docházelo při poměrně častých haváriích (až 500 za rok) a při únicích jinak specifických látek, které nebyly ani monitorovány. Vedle intenzivního zemědělství a rozvíjejícího se průmyslu byla značným zdrojem znečištění sídla bez čistíren odpadních vod nebo s čistírnami pouze částečně funkčními.

Nejvýznamnější změna jakosti vody nastala v 90 . letech minulého století. Politické změny a ekonomická deprese provázená recesí průmyslu i zemědělství se výrazně projevila na snížení koncentrací znečištujících látek ve vodách. V následném období se snížil počet především bodových zdrojů znečištění a to jednak vlivem již zmiňované recese průmyslové výroby a jednak výstavbou a rekonstrukcí čistíren odpadních vod, iniciovanou mezinárodním tlakem a značnou především finanční podporou. Díky těmto krokům se výrazně snížily koncentrace zejména amoniakálního dusíku a organických látek.

Kvalita vody se tedy v národním měřítku zlepšila a tento trend díky dalším opatřením stále pokračuje. Do popredí se také dostal další rozměr vodního prostředí - jeho ekologická hodnota a to zejména díky změně pohledu na přírodní bohatství. Díky tomuto procesu byl pro vodní prostředí ustanoven program Revitalizace říčních systémů, z něhož plynou zdroje na uvedení částí vodního prostředí do přírodě blízkého stavu.

Obr. 1 - Pracovní skupina „kvalita vody“ připravuje prezentaci.

Obr. 2 - Relativní změna tříd jakosti vody v České republice v letech 1991-1992 a 1999-2000. Osa x - třídy jakosti vody, osa y - procentuální změna. Zdroj: Ministerstvo životního prostředí, www.env.cz.

Obr. 3 - Finanční prostředky poskytnuté programu Revitalizace říčních systémů v České Republice. Osa x - roky, osa y - objem financí (mil. EUR). Zdroj: Ministerstvo životního prostředí, www.env.cz. V letech 1992-2002 bylo realizováno téměř 2000 projektů a investováno 2,4 miliard Kč (75,5 milionů EUR). V prvním období (1992-1995) byly financovány menší projekty (0,5-1,5 milionů Kč). Ve druhém období (1996-2002) převažovaly větší projekty (1-3 miliony Kč).

Obr. 4 - Návštěva revitalizované části povodí Stropnice.

(K. Alamets is a student of University of Tartu, Estonia, e-mail: kevelyn@ut.ee. $M$.

Bicanová is a student of Charles University, Faculty of Science, Czechia, e-mail: madlabi@hotmail.com.P. Judová is PGS student of Charles University, Faculty of Science, Czechia, e-mail: petra.judova@email.cz. H. Pärnamets is a student of University of Tartu, Estonia, e-mail: Henn.Parnamets@ekm.envir.ee. L. Ronczyk is a student University of Pecs, Hungary, e-mail: ronczykl@freemail.hu. S. Rödlová is PGS student of Charles University, Faculty of Science, Czechia, e-mail: sylva.rodlova@seznam.cz.)

Members of Working Group II: Water quality and restoration of water ecosystems: Belen Pedregal, Daria Quatrida, Chiara Zanini, Christian Hauzar, István Fodor, Karolina Macháčková, Lara Marchiol, Martin Hais, Massimo De Marchi, Milada Matoušková. 